Table 2. Interatomic distances in $\mathrm{V}_{2} \mathrm{P}$ ( $\AA$ units). Distances shorter than 3.5 $\AA$ are listed. The estimated standard deviations are smaller than $0.001 \AA$ for all distances.

\begin{tabular}{cccc}
$V(1)-2 P$ & 2.341 & $V(2)-2 P$ & 2.461 \\
$-\mathbf{P}$ & 2.366 & $-2 P$ & 2.547 \\
$-\mathbf{P}$ & $\mathbf{2 . 4 7 4}$ & $-\mathbf{P}$ & 2.674 \\
$-2 V(1)$ & 2.545 & $-2 V(1)$ & 2.716 \\
$-2 V(2)$ & 2.716 & $-2 V(1)$ & 2.872 \\
$-2 V(2)$ & 2.872 & $-V(1)$ & 3.013 \\
$-V(2)$ & 3.013 & $-V(1)$ & 3.025 \\
$-V(2)$ & 3.025 & $-2 V(2)$ & 3.043 \\
$-2 V(1)$ & 3.305 & $-2 V(2)$ & 3.305 \\
& & $-2 V(2)$ & 3.349 \\
$\mathbf{P}-2 P$ & 3.305 & & \\
\hline
\end{tabular}

single-crystal analysis showed that $V_{2} P$ is indeed a new member of this class.

It is interesting to compare the atomic ar. rangement of $V, P$ with that of the isotypic $\mathbf{R u}_{2} \mathbf{P}{ }^{7}$ since the metal radii are approximately equal. Different arrangements are found, which implies that the radius ratio is not the governing factor. The $b$-axis of $R u_{2} P$ is $3.859 \AA$ while that of $\mathrm{V}_{2} \mathrm{P}$ is only $3.305 \AA$. Thus the trigonal prisms in $\mathrm{V}_{2} \mathrm{P}$ are contracted compared to those in $R u_{2} P$, which demand the metal atoms outside the prism faces to be positioned further away from the central phosphorus atom. These $\mathbf{M}-\mathbf{P}$ distances are then longer while within the prisms the $M-P$ distances as well as the $\mathbf{M}-\mathbf{M}$ distances are shorter than in $\mathbf{R u}_{2} \mathbf{P}$. This leads to a more even distribution of the $\mathbf{M}-\mathbf{P}$ distances but a larger spread of the $\mathbf{M}-\mathbf{M}$ distances in $\mathbf{V}_{2} \mathbf{P}$. These geometrical aspects were introduced and thoroughly discussed by Rundqvist. ${ }^{12}$ The interatomic distances in $V_{2} P$ are presented in Table 2, using the same notation as Rundqvist. The mean $V(1)-P$ distance is $2.38 \AA$ and the mean $\mathrm{Ru}(1)-\mathrm{P}$ distance is $2.34 \AA$. Corresponding averages for the $M(2)-P$ distances are 2.54 and $2.61 \AA$ for $V_{2} P$ and $\mathrm{Ru}_{2} \mathrm{P}$, respectively. The shortest $M-M$ distance in $R u_{2} P$ is $2.74 \AA$ as compared to $2.55 \AA$ in $\mathrm{V}_{2} \mathrm{P}$, the latter distance being shorter than a normal metal contact. Short intermetallic distances are not uncommon in vanadium-rich compounds with Group 4 or 5 elements.

Acknowledgement. Financial support from the Swedish Natural Science Research Council is gratefully acknowledged.

1. Berger, R. Acta Chem. Scand. A 29 (1975) 641 .

2. Boller, H. Monatsh. Chem. 104 (1973) 48.

3. Andrew, T. R. Analyst 82 (1957) 423 .
4. Gustafsson, L. University of Uppsala. Private communication.

5. Deslattes, R. D. and Henins, A. Phys. Rev. Lett. 31 (1973) 972.

6. Lundgren, J.-O., Ed., Crystallographic Computer Programs, Institute of Chemistry, University of Uppsala, Uppsala 1975, UUIC-B13-04-2.

7. Rundqvist, S. Acta Chem. Scand. 14 (1960) 1961.

8. Hanson, H. P., Herman, F., Lea, J. D. and Skillman, S. Acta Crystallogr. 17 (1964) 1040.

9. Cromer, D. T. Acta Crystallogr. 18 (1965) 17.

10. Hirshfeld, F. L. and Rabinovich, D. Acta Crystallogr. A 29 (1973) 510.

11. Rundqvist, S. Acta Chem. Scand. 15 (1961) 342.

12. Rundqvist, S. Ark. Kemi 20 (1962) 67.

13. Shoemaker, C. B. and Shoemaker, D. P. Acta Crystallogr. 18 (1965) 900.

Received February 5, 1976.

\section{On the Compound $\mathrm{La}_{4} \mathrm{Co}_{3} \mathrm{O}_{10}$}

\section{SEPPÄNEN and M. H. TIKKANEN}

Department of Mining and Metallurgy, The Helsinki University of Technology, SF.02150 Espoo 15, Finland

Some binary oxides, of general formulae $\mathrm{AO}$ and $\mathrm{BO}_{2}$, form ternary compounds $\mathrm{AO}\left(\mathrm{ABO}_{3}\right)_{n}$, where one at the one end finds the perovskite $\mathrm{ABO}_{3}(n=\infty)$ type structure and at the other the $\mathrm{A}_{2} \mathrm{BO}_{4}(n=1)$ the $\mathrm{K}_{2} \mathrm{NiF}_{4}$ type. Two further members of a series are known, viz. $\mathrm{A}_{3} \mathrm{~B}_{2} \mathrm{O}_{2}$ $(n=2)$ and $\mathrm{A}_{4} \mathrm{~B}_{3} \mathrm{O}_{10}(n=3)$, but none has re. ported examples for $n$ between 3 and $\infty$. The structure of $\mathrm{AO}\left(\mathrm{ABO}_{8}\right)_{n}$ contains $n$ perovskite sheets separated by an $\mathrm{AO}$ sheet of $\mathrm{NaCl}$ like structure. Such series are known in the systems $\mathrm{CaO}-\mathrm{MnO}_{2}, \mathrm{CaO}-\mathrm{TiO}_{2}, \mathrm{SrO}-\mathrm{MnO}_{2}, \mathrm{SrO}-$ $\mathrm{TiO}_{2}$, and $\mathrm{SrO}_{-} \mathrm{ZrO}_{2}{ }^{1}$

In the system $\mathrm{La}-\mathrm{Co}-\mathrm{O} \mathrm{LaCoO}_{3}$ and $\mathrm{La}_{2} \mathrm{CoO}_{4}$ with rhombohedrally modified perovskite and orthorhombic $\mathrm{K}_{2} \mathrm{NiF}_{4}$ type structures 2,3 are known. We have prepared $\mathrm{La}_{4} \mathrm{Co}_{3} \mathrm{O}_{10}, 4$ which also has been reported quite recently by Janecek and Wirtz. ${ }^{5}$

Experimental. Initial batches of $\mathrm{LaCoO}_{3}$ and $\mathrm{La}_{2} \mathrm{CoO}_{4}$ were prepared from $99.99 \% \mathrm{La}_{2} \mathrm{O}_{2}$ (Kemira OY) and $99.95 \% \mathrm{CoO}$ (Sheritt Gor. don). Powder mixtures were coldpressed at $9.8 \mathrm{kN} / \mathrm{cm}^{2}$. $\mathrm{LaCoO}_{3}$-specimens were fired for one week at $1100{ }^{\circ} \mathrm{C}$ in oxygen atmosphere and $\mathrm{La}_{2} \mathrm{CoO}_{4}$-tablets for four days at $1300^{\circ} \mathrm{C}$ in argon $\left(P_{2} \approx 10^{-6}\right.$ bar $)$ with frequent inter.

Acta Chem. Scand. A 30 (1976) No. 5 
Table 1. X-Ray powder data of $\mathrm{La}_{4} \mathrm{Co}_{3} \mathrm{O}_{10}$.

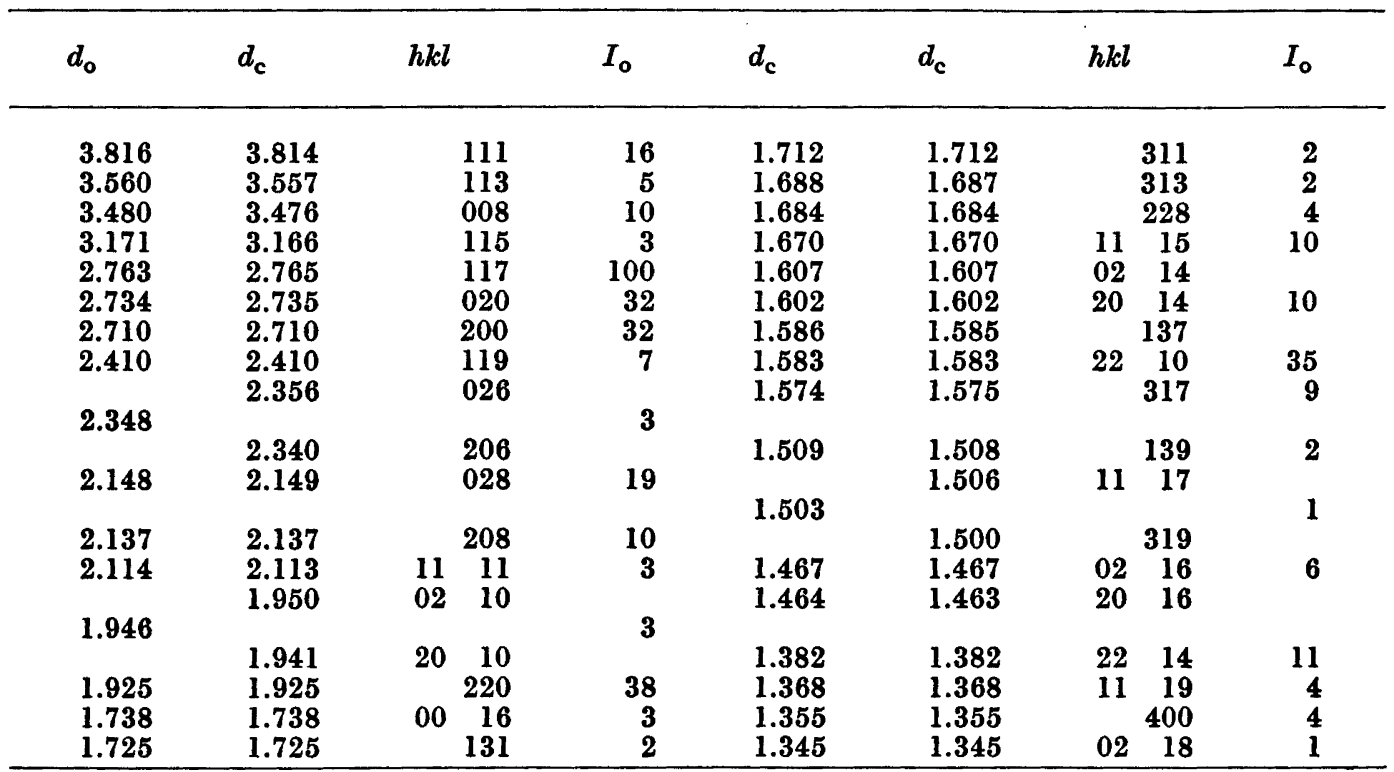

mediate grindings. $\mathrm{La}_{4} \mathrm{Co}_{3} \mathrm{O}_{10}$-specimens were finally prepared from $\mathrm{LaCoO}_{3}$ and $\mathrm{La}_{2} \mathrm{CoO}_{4}$ powders kept at $1130^{\circ} \mathrm{C}$ in nitrogen atmosphere $\left(p \mathrm{O}_{2}=10^{-3.95} \mathrm{bar}\right)$ for five days.

The powder pattern of $\mathrm{La}_{4} \mathrm{Co}_{3} \mathrm{O}_{10}$ was run by X-ray diffractometer PW $1410 / 20$ using graphite monochromatized $\mathrm{CuK} \alpha$-radiation $(\lambda=1.5418 \AA)$ at a scanning speed of $0.25^{\circ} / \mathrm{min}$ and a silicon powder $(a=\mathbf{5 . 4 3 0 1} \AA)$ as an internal standard.

The powder pattern of $\mathrm{La}_{4} \mathrm{Co}_{3} \mathrm{O}_{10}$ was satis. factorily indexed with orthorhombic unit cell parameters, $a=5.42 \AA, b=5.47 \AA$ and $c=$ $27.81 \AA$. The measured density, $7.1 \mathrm{~g} \mathrm{~cm}^{-3}$, corresponds to four formula units per cell $\left(\mathrm{D}_{\mathrm{x}}=7.21 \mathrm{~g} \mathrm{~cm}^{-3}\right)$. All indexes are unmixed, Table 1 , so a possible space group is $F \mathrm{mmm}$ (No. 69).

In our investigation of the $\mathrm{La}-\mathrm{Co}-\mathrm{O}$. system we have obtained no evidence for $\mathrm{La}_{3} \mathrm{Co}_{2} \mathrm{O}_{7}$. We shall later report on thermodynamic investigations of the system La$\mathrm{Co}-\mathrm{O}$ and also the powder pattern of $\mathrm{La}_{4} \mathrm{Ni}_{3} \mathrm{O}_{10}$.

Acknowledgements. This research has been performed with financial support from the Finnish Natural Science Research Foundation and the Jenny and Antti Wihuri Fund.

1. Goodenough, J. B. and Longo, J. LandoltBörnstein Tabellen Neue Serie III/4a, p. 203, Springer (Berlin) 1970.
2. Rabenau, A. and Eckerlin, P. Acta Crystallogr. 11 (1958) 304.

3. Lehuede, P. and Daire, M. C. R. Acad. Sci. 276 (1973) 1783.

4. Tikkanen, M. H. and Seppänen, M. Research Report for the Academy of Finland, Part 1, Febr. 1975 .

5. Janecek, J. J., Wirtz, G. P. Am. Ceram. Soc. Bull. 54 (1975) 739.

Received February 16, 1976. 